\title{
Zopfiellasins A-D, Two Pairs of Epimeric Cytochalasins from Kiwi-Associated Fungus Zopfiella sp. and Their Antibacterial Assessment
}

\author{
Jie-Yu Zhang ${ }^{1}$, Juan He ${ }^{1}$, Zheng-Hui Li ${ }^{1,2}$, Tao Feng ${ }^{1,2, *}$ and Ji-Kai Liu ${ }^{1,2, *}$ \\ 1 School of Pharmaceutical Sciences, South-Central University for Nationalities, Wuhan 430074, China; \\ zhangjieyu98@163.com (J.-Y.Z.); 2015048@mail.scuec.edu.cn (J.H.); 2015051@mail.scuec.edu.cn (Z.-H.L.) \\ 2 National Demonstration Center for Experimental Ethnopharmacology Education, South-Central University \\ for Nationalities, Wuhan 430074, China \\ * Correspondence: tfeng@mail.scuec.edu.cn (T.F.); liujikai@mail.scuec.edu.cn (J.-K.L.)
}

\section{check for}

updates

Citation: Zhang, J.-Y.; He, J.; Li, Z.-H.; Feng, T.; Liu, J.-K. Zopfiellasins A-D, Two Pairs of Epimeric Cytochalasins from Kiwi-Associated Fungus Zopfiella sp. and Their Antibacterial Assessment. Molecules 2021, 26, 5611. https://doi.org/ $10.3390 /$ molecules 26185611

Academic Editors: Minghua Qiu, De-An Guo, Pengfei Tu and Wencai Ye

Received: 22 August 2021

Accepted: 13 September 2021

Published: 16 September 2021

Publisher's Note: MDPI stays neutral with regard to jurisdictional claims in published maps and institutional affiliations.

Copyright: (c) 2021 by the authors. Licensee MDPI, Basel, Switzerland. This article is an open access article distributed under the terms and conditions of the Creative Commons Attribution (CC BY) license (https:/ / creativecommons.org/licenses/by/ $4.0 /)$.

\begin{abstract}
In our continuous search for antibacterial agents against Pseudomonas syringae pv. actinidiae (Psa) from kiwi-associated fungi, two pairs of epimeric cytochalasins, zopfiellasins A-D (1-4), were characterized from the fungus Zopfiella sp. The structures were established on the basis of spectroscopic data analysis, while the absolute configurations were determined by single-crystal X-ray diffraction. Compounds 1 and 3 exhibited antibacterial activity against Psa with MIC values of 25 and $50 \mu \mathrm{g} / \mathrm{mL}$, respectively. This is the first report of anti-Psa activity of cytochalasin derivatives.
\end{abstract}

Keywords: Zopfiella sp.; cytochalasins; Pseudomonas syringae pv. actinidiae; antibacterial

\section{Introduction}

Kiwi is a fruit produced by Actinidia chinensis and various artificially cultivated varieties. It enjoys great reputation all over the world, and is cultivated in large numbers in many countries [1,2]. Kiwifruit inevitably suffers from many pests and diseases which affect the industry. The most devastating disease is kiwi canker, caused by Pseudomonas syringae pv. actinidiae (Psa) [2-6]. Currently, the main methods for the treatment of canker include copper preparation pesticides and biological control [7-9]. Although some recent chemical fungicides, such as peptides [10], neolignans [11], 1,4-benzoxazin-3-one derivatives [12], and synthetic 1,2,3-triazole-tailored carbazoles [13], have good antibacterial activity against Psa, there are increasing concerns about the harmful impacts of chemical fungicide residues on human health and the environment. Therefore, there is still a lack of safe and effective prevention methods for canker disease. Endophytic fungi, due to the process of co-evolution with the host plants, produce a series of active secondary metabolites. Our strategy is to find anti-Psa agents from kiwi-associated fungi. According to a lot of screening work, one of the kiwi-associated fungi, Zopfiella sp, exhibits good inhibitory activity on Psa, and chemical investigations on this fungus have been carried out. Previously, bisabolane sesquiterpenes, $\alpha$-pyrone derivatives, and 3-decalinoyltetramic acid derivatives have been isolated from this fungus [14,15], while the 3-decalinoyltetramic acid derivatives such as zofielliamides A, B, and D showed anti-Psa activity with MIC values of 64,32 , and $64 \mu \mathrm{g} / \mathrm{mL}$, respectively [15]. In this study, four cytochalasins, namely zopfiellasins A-D (1-4), are characterized from Zopfiella sp. (Figure 1). The structures with absolute configurations have been established by means of spectroscopic methods as well as single-crystal X-ray diffraction. All compounds were evaluated for their antibacterial activity against Psa. Herein, the isolation, structure elucidation, and antibacterial activity of these compounds are described. 


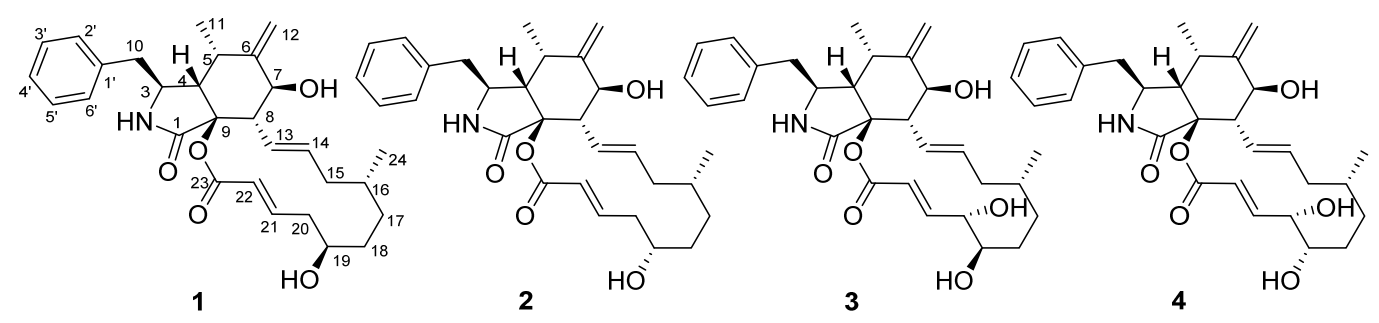

Figure 1. Chemical structures of compounds 1-4.

\section{Results and Discussion}

\subsection{Structural Identification of Compounds 1-4}

Compound $\mathbf{1}$ was isolated as colorless crystals, while compound $\mathbf{2}$ was isolated as white powder. They were identified as a pair of epimers whose molecular formulae were established to be $\mathrm{C}_{29} \mathrm{H}_{37} \mathrm{NO}_{5}$ on the basis of HRESIMS data, corresponding to 12 degrees of unsaturation. Their ${ }^{13} \mathrm{C}-\mathrm{NMR}$ spectra (Table 1. For original spectra, please see the Supplementary Materials) showed 29 carbon resonances ascribable for $2 \mathrm{CH}_{3}, 6 \mathrm{CH}_{2}, 16 \mathrm{CH}$, and 5 non-protonated carbons. In combination with ${ }^{1} \mathrm{H}-\mathrm{NMR}$ data, a mono-substituted phenyl, two trans double bonds, a terminal double bond, and two carbonyl carbons were readily identified. All these data suggested that 1 and $\mathbf{2}$ should be two cytochalasin derivatives [16-20]. Analysis of ${ }^{1} \mathrm{H}-{ }^{1} \mathrm{H}$ COSY data revealed several fragments, as shown in Figure 2. In addition, a detailed analysis of HMBC data suggested that $\mathbf{1}$ and $\mathbf{2}$ should have a similar structure to that of the known compound cytochalasin Z3 [16]. However, the configuration of C-19 in cytochalasin Z3 was not established. The single-crystal X-ray diffraction on compound 1 suggested C-19 to be $R$ form, which allowed C-19 in compound 2 to be $S$ form. This finding was supported by the ROESY analysis as well as the coupling constant modification of $\mathrm{H}-19$ in $\mathbf{2}$. Therefore, the structures of compounds $\mathbf{1}$ and $\mathbf{2}$ were identified and named as zopfiellasins A and B, respectively.

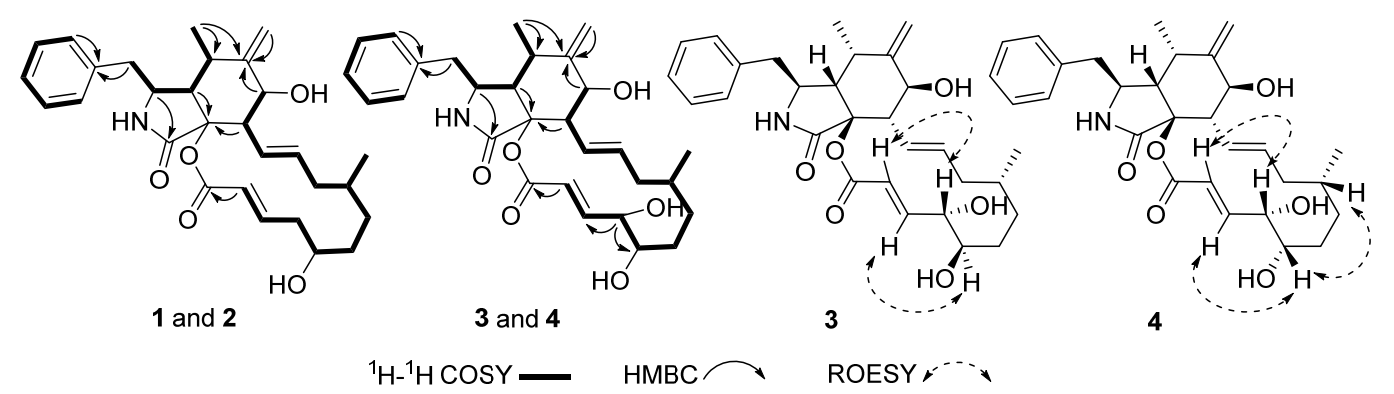

Figure 2. Key 2D-NMR correlations for compounds 1-4.

Compounds 3 (colorless crystals) and 4 (white solid) were also isolated as a pair of epimers. They possessed a molecular formula $\mathrm{C}_{29} \mathrm{H}_{37} \mathrm{NO}_{5}$ that was established by the HRESIMS data. The 1D and 2D-NMR data of $\mathbf{3}$ and $\mathbf{4}$ were similar to those of $\mathbf{1}$ and $\mathbf{2}$ (Table 1). The MS data of 3 and $\mathbf{4}$ showed 16 mass units more than $\mathbf{1}$ and 2, indicating that 3 and $\mathbf{4}$ should be oxidization products of $\mathbf{1}$ or $\mathbf{2}$. Analysis of ${ }^{1} \mathrm{H}-{ }^{1} \mathrm{H}$ COSY and $\mathrm{HMBC}$ data indicated that $\mathbf{3}$ and $\mathbf{4}$ possessed one more hydroxy group at C-20 (Figure 2). Fortunately, the structure with the absolute configuration of $\mathbf{3}$ was determined according to singlecrystal X-ray diffraction (Figure 3). In order to elucidate the stereoconfiguration of 4, a detailed analysis of ROESY data between 3 and 4 was conducted. Although C-19 and C-20 in compounds 3 and 4 are in a 14-membered ring system, the existence of two trans double bonds makes the ring in a rigid state. Therefore, the differences in the stereoconfiguration can be detected by comparing their ROESY correlations. The ROESY data of 4 revealed almost the same patterns as those of 3 . However, the key correlation between H-19 and H-16 in 4 (Figure 2), not observed in the ROESY spectrum of 3, suggested that C-19 in 4 should be $S$ form, rather than $R$ form in 3 . Therefore, compound 4 was elucidated as 
19-epimer of $\mathbf{3}$. Finally, the structures of $\mathbf{3}$ and $\mathbf{4}$ were established and named zopfiellasins $\mathrm{C}$ and $\mathrm{D}$, respectively.

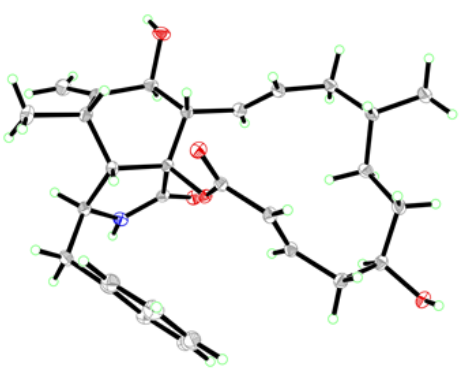

1

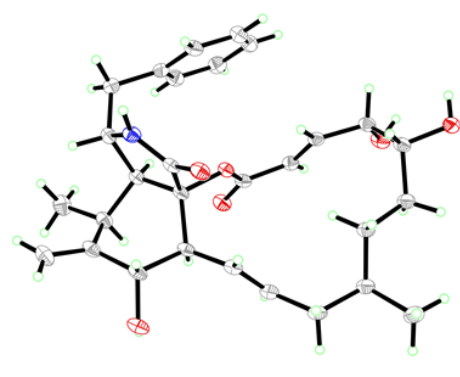

3

Figure 3. ORTEP diagrams of 1 and 3.

\subsection{Antibacterial Activity against Psa}

Compounds 1-4 were evaluated for their antibacterial activity against Psa using the previously reported method [11]. As a result, compounds $\mathbf{1}$ and $\mathbf{3}$ exhibited certain inhibitory activity on Psa with MIC values of 25 and $50 \mu \mathrm{g} / \mathrm{mL}$. A brief analysis of their structure-activity relationship suggested that the stereoconfiguration of C-19 might play an important role in their antibacterial ability. The $S$ form of $C-19$ in compounds 2 and 4 made them inactive. As introduced before, 3-decalinoyltetramic acid derivatives from this fungus also exhibited anti-Psa activity with MICs of 32 and $64 \mu \mathrm{g} / \mathrm{mL}$. Therefore, cytochalasins and 3-decalinoyltetramic acid derivatives are suggested to be active compounds against Psa in the fungus Zopfiella sp. Searching for more related compounds from this fungus should be a good strategy for the discovery of anti-Psa agents.

\section{Materials and Methods}

\subsection{Materials and Instruments}

Melting points were obtained on an X-4 micro melting point apparatus (Yuhua Instrument Company, Gongyi, China). Optical rotations (OR) were recorded on a JASCO P-1020 digital polarimeter (Horiba, Kyoto, Japan). UV spectra were measured on a UH5300 UV-vis double beam spectrophotometer (Hitachi High-Technologies, Tokyo, Japan). IR spectra were carried out using a Shimadu Fourier transform infrared spectrometer with KBr pellets (Shimadu Corporation, Kyoto, Japan). NMR spectra were acquired with a Bruker Avance III 600 instrument (Bruker, Karlsruher, Germany). High-resolution electrospray ionization mass spectra (HRESIMS) were recorded on a LC-MS system consisting of a Q Exactive ${ }^{\mathrm{TM}}$ Orbitrap mass spectrometer with an ESI ion source used in an ultra-high resolution mode and a Dionex UltiMate 3000 RSLC UPLC system (ThermoFisher Scientific, Bremen, Germany). Crystallographic data were collected on a Bruker D8 QUEST diffractometer using graphite-monochromated $\mathrm{Cu} \mathrm{K} \alpha$ radiation. Silica gel (200-300 mesh and 500-800 mesh), RP-18 gel (40-75 $\mu \mathrm{m})$, and Sephadex LH-20 were used for column chromatography (CC). Preparative HPLC was performed on an Agilent 1260 liquid chromatography system (Agilent Technologies, Santa Clara, CA, USA) with a Zorbax SB-C18 (5 $\mu \mathrm{m}, 9.4 \mathrm{~mm} \times 150 \mathrm{~mm})$ column and a D-detector.

\subsection{Fungal Material and Cultivation Conditions}

The fungus Zopfiella sp. was isolated from healthy tissue of the kiwi plant (Actinidia chinensis Planch). It was identified as a species of the genus Zopfiella by ITS sequencing with an accession number KR154941.1. Further identification of this fungus is ongoing. Culture medium consists of glucose $(5 \%)$, pork peptone $(0.15 \%)$, yeast $(0.5 \%), \mathrm{KH}_{2} \mathrm{PO}_{4}(0.05 \%)$ and $\mathrm{MgSO}_{4}(0.05 \%)$. Initial $\mathrm{pH}$ was adjusted to 6.0 , and the fermentation was initially implemented on an Erlenmeyer flask for 6 days until the mycelium biomass reached the maximum. Following this, it was transferred to rice medium for $24^{\circ} \mathrm{C}$ in dark culture for 
30 days. Rice medium: $75 \mathrm{~g}$ of rice, $75 \mathrm{~mL}$ of water, placed in a $250 \mathrm{~mL}$ Erlenmeyer flask, sterilized at $121{ }^{\circ} \mathrm{C}$ for $15 \mathrm{~min}$, a total of 200 bottles.

\subsection{Extraction and Isolation}

The rice cultural broth $(15 \mathrm{~kg})$ was extracted five times with EtOAc. The EtOAc layer was concentrated under reduced pressure to give an oily crude extract $(200 \mathrm{~g})$. The extract (200 g) was subjected to CC on silica gel (200-300 mesh) with a gradient of $\mathrm{CHCl}_{3} / \mathrm{MeOH}$ $(1: 0,40: 1,20: 1,10: 1,5: 1,2: 1,0: 1, v / v)$ to obtain seven fractions (A-G). Fraction B (12 g) was further separated by silica gel CC with a gradient of petroleum ether/acetone (from 10:1 to 2:1) to give eight subfractions B1-B8. Fraction B3 $(600 \mathrm{mg})$ was prepared by HPLC $\left(\mathrm{CH}_{3} \mathrm{CN}-\mathrm{H}_{2} \mathrm{O}\right.$ from 30:70 to 60:40, v/v, $\left.25 \mathrm{~min}\right)$ to give compound $\mathbf{1}(11 \mathrm{mg})$ and a mixture. The latter was purified by CC over Sephadex $\mathrm{LH}-20(\mathrm{MeOH})$ to give compound $2(3 \mathrm{mg})$. Fraction $\mathrm{B} 6(310 \mathrm{mg})$ was prepared by HPLC $\left(\mathrm{CH}_{3} \mathrm{CN}-\mathrm{H}_{2} \mathrm{O}\right.$ from 30:70 to 50:50, v/v, $\left.25 \mathrm{~min}\right)$ to give compounds $3(7 \mathrm{mg})$ and $4(8 \mathrm{mg})$.

Zopfiellasin A (1): Colorless crystals, mp: $220-222{ }^{\circ} \mathrm{C} ;[\alpha]^{24} \mathrm{D}+114.5(\mathrm{c} 0.16, \mathrm{MeOH})$; ${ }^{1} \mathrm{H}-\mathrm{NMR}\left(600 \mathrm{MHz}\right.$, methanol- $\left.d_{4}\right)$ and ${ }^{13} \mathrm{C}-\mathrm{NMR}\left(150 \mathrm{MHz}\right.$, methanol- $\left.d_{4}\right)$ data, see Table 1 ; HRESIMS $\mathrm{m} / z$ 480.27461 [M + H] $]^{+}$(calcd for $\mathrm{C}_{29} \mathrm{H}_{38} \mathrm{NO}_{5}{ }^{+}$: 480.27445).

Zopfiellasin B (2): White powder; $[\alpha]^{24} \mathrm{D}+130.1$ (c $\left.0.35, \mathrm{MeOH}\right) ; \mathrm{UV}(\mathrm{MeOH}) \lambda_{\max }(\log \varepsilon)$ 215 (3.82) nm; ${ }^{1} \mathrm{H}-\mathrm{NMR}\left(600 \mathrm{MHz}\right.$, methanol- $\left.d_{4}\right)$ and ${ }^{13} \mathrm{C}-\mathrm{NMR}\left(150 \mathrm{MHz}\right.$, methanol- $\left.d_{4}\right)$ data, see Table 1; HRESIMS $m / z 480.27446[\mathrm{M}+\mathrm{H}]^{+}$(calcd for $\mathrm{C}_{29} \mathrm{H}_{38} \mathrm{NO}_{5}{ }^{+}: 480.27445$ ).

Zopfiellasin C (3): Colorless crystals, mp: $219-220{ }^{\circ} \mathrm{C} ;[\alpha]^{24} \mathrm{D}+63.5$ (c $\left.0.80, \mathrm{MeOH}\right) ; \mathrm{UV}$ $(\mathrm{MeOH}) \lambda_{\max }(\log \varepsilon) 210(3.76) \mathrm{nm}$; IR (KBr) $v_{\max } 3423,1651,1277,1102,1016,974,703 \mathrm{~cm}^{-1}$; ${ }^{1} \mathrm{H}-\mathrm{NMR}\left(600 \mathrm{MHz}\right.$, methanol- $\left.d_{4}\right)$ and ${ }^{13} \mathrm{C}-\mathrm{NMR}\left(150 \mathrm{MHz}\right.$, methanol- $\left.d_{4}\right)$ data, see Table 1 ; HRESIMS $m / z 496.26932[\mathrm{M}+\mathrm{H}]^{+}$(calcd for $\mathrm{C}_{29} \mathrm{H}_{38} \mathrm{NO}_{6}{ }^{+}$: 496.26936).

Zopfiellasin D (4): White solid; $[\alpha]^{24} \mathrm{D}+87.6$ (c 0.21, MeOH); UV (MeOH) $\lambda_{\max }(\log \varepsilon) 215$ (3.82) nm; ${ }^{1} \mathrm{H}-\mathrm{NMR}\left(600 \mathrm{MHz}\right.$, methanol- $\left.d_{4}\right)$ and ${ }^{13} \mathrm{C}-\mathrm{NMR}\left(150 \mathrm{MHz}\right.$, methanol- $\left.d_{4}\right)$ data, see Table 1; HR-ESI-MS $m / z 496.26950[\mathrm{M}+\mathrm{H}]^{+}$(calcd for $\mathrm{C}_{29} \mathrm{H}_{38} \mathrm{NO}_{6}{ }^{+}$: 496.26936).

Crystal Data for Zopfiellasin A (1). $\mathrm{C}_{29} \mathrm{H}_{37} \mathrm{NO}_{5}, M=479.59 a=10.1460$ (4) $\AA, b=11.9673$ (5) $\AA, c=21.3369$ (8) $\AA, \alpha=90.00^{\circ}, \beta=90.00^{\circ}, \gamma=90.00^{\circ}, V=2590.73(18) \AA^{3}, T=151$ (2) K. $a=9.2386$ (2) $\AA, b=11.0791$ (2) $\AA, c=26.7495$ (6) $\AA, \alpha=90^{\circ}, \beta=90^{\circ}, \gamma=90^{\circ}, V=2737.96$ (10) $\AA^{3}, T=298(2) \mathrm{K}$, space group P21 $2121, Z=4, \mu(\mathrm{Cu} \mathrm{K \alpha})=1.54178 \mathrm{~mm}^{-1}$. A total of 33,559 reflections were measured, of which 5559 were independent $\left(R_{\text {int }}=4.22 \%\right)$. The final anisotropic full-matrix least-squares refinement on $\mathrm{F}^{2}$ with 326 variables converged at $R_{1}=3.02 \%$, for the observed data and $w R_{2}=7.62 \%$ for all data. The goodness of fit was 1.032. The absolute configuration was determined by the Flack parameter $=0.02(4)$ CCDC: 2,104,459 (https: / / www.ccdc.cam.ac.uk).

Crystal data for Zopfiellasin C (3). $\mathrm{C}_{29} \mathrm{H}_{37} \mathrm{NO}_{6} \cdot \mathrm{CH}_{3} \mathrm{OH}, M=527.64, a=10.4883(6) \AA$, $b=23.6229(13) \AA, c=11.8002(6) \AA, \alpha=90.00^{\circ}, \beta=90.452(2)^{\circ}, \gamma=90.00^{\circ}, V=2923.6(3)$ $\AA^{3}, T=150(2) \mathrm{K}$, space group $P 1211, \mathrm{Z}=4, \mu(\mathrm{Cu} \mathrm{K} \alpha)=0.687 \mathrm{~mm}^{-1}$. A total of 69,193 reflections were measured, of which 12,495 were independent $\left(R_{\text {int }}=6.72 \%\right)$. The final anisotropic full-matrix least-squares refinement on $\mathrm{F}^{2}$ with 717 variables converged at $R_{1}=4.06 \%$, for the observed data and $\mathrm{w} R_{2}=10.97 \%$ for all data. The goodness of fit was 1.016. The absolute configuration was determined by the Flack parameter $=0.06(5)$. CCDC: 2,104,583 (https: / / www.ccdc.cam.ac.uk). 
Table 1. ${ }^{1} \mathrm{H}(600 \mathrm{MHz})$ and ${ }^{13} \mathrm{C}(150 \mathrm{MHz})-\mathrm{NMR}$ data for compounds $\mathbf{1 - 4}$ in methanol- $d_{4}$.

\begin{tabular}{|c|c|c|c|c|c|c|c|c|}
\hline \multirow{2}{*}{ No. } & \multicolumn{2}{|c|}{1} & \multicolumn{2}{|c|}{2} & \multicolumn{2}{|c|}{3} & \multicolumn{2}{|c|}{4} \\
\hline & $\delta_{\mathrm{C}}$ & $\delta_{\mathrm{H}}(J$ in $\mathrm{Hz})$ & $\delta_{\mathrm{C}}$ & $\delta_{\mathrm{H}}(J$ in $\mathrm{Hz})$ & $\delta_{\mathrm{C}}$ & $\delta_{\mathrm{H}}(J$ in $\mathrm{Hz})$ & $\delta_{\mathrm{C}}$ & $\delta_{\mathrm{H}}(J$ in $\mathrm{Hz})$ \\
\hline 1 & $174.0, \mathrm{C}$ & & $173.8, \mathrm{C}$ & & $174.0, \mathrm{C}$ & & $173.9, \mathrm{C}$ & \\
\hline 3 & $54.9, \mathrm{CH}$ & $3.37, \operatorname{td}(6.1,2.7)$ & $55.2, \mathrm{CH}$ & $3.34, \mathrm{~m}$ & $54.7, \mathrm{CH}$ & $3.40, \mathrm{~m}$ & $54.9, \mathrm{CH}$ & $3.38, \mathrm{~m}$ \\
\hline 4 & $48.7, \mathrm{CH}$ & $2.82, \mathrm{~m}$ & $49.3, \mathrm{CH}$ & 2.76, dd $(4.7,3.2)$ & $48.4, \mathrm{CH}$ & $2.86, \mathrm{~d}(2.8)$ & $48.7, \mathrm{CH}$ & $2.82, \mathrm{~d}(5.9)$ \\
\hline 5 & $32.8, \mathrm{CH}$ & $3.17, \mathrm{~m}$ & $33.0, \mathrm{CH}$ & $3.11, \mathrm{~m}$ & $32.8, \mathrm{CH}$ & $3.22, \mathrm{~m}$ & $32.9, \mathrm{CH}$ & $3.19, \mathrm{~m}$ \\
\hline 6 & $151.4, \mathrm{C}$ & & $151.6, \mathrm{C}$ & & $151.4, \mathrm{C}$ & & $151.5, \mathrm{C}$ & \\
\hline 7 & $71.2, \mathrm{CH}$ & $3.78, \mathrm{dd}(10.9,0.8)$ & $70.6, \mathrm{CH}$ & $3.81, \mathrm{dd}(11.3,1.1)$ & $71.6, \mathrm{CH}$ & $3.78, \mathrm{~d}(10.7)$ & $71.2, \mathrm{CH}$ & $3.80, \mathrm{~d}(11.0)$ \\
\hline 8 & $49.6, \mathrm{CH}$ & $3.34, \mathrm{~m}$ & $50.6, \mathrm{CH}$ & 3.18 , dd $(11.1,9.9)$ & $49.0, \mathrm{CH}$ & $3.38, \mathrm{~m}$ & $49.4, \mathrm{CH}$ & $3.31, \mathrm{~m}$ \\
\hline 9 & $85.2, \mathrm{C}$ & & $84.7, \mathrm{C}$ & & $85.5, \mathrm{C}$ & & $85.4, \mathrm{C}$ & \\
\hline 10 & $43.9, \mathrm{CH}_{2}$ & $2.82, \mathrm{~m} ; 2.82, \mathrm{~m}$ & $43.9, \mathrm{CH}_{2}$ & $2.89, \mathrm{~m} ; 2.89, \mathrm{~m}$ & $43.9, \mathrm{CH}_{2}$ & $2.78, \mathrm{~d}(5.7)$ & $43.9, \mathrm{CH}_{2}$ & $2.82, \mathrm{~d}(5.9)$ \\
\hline 11 & $14.2, \mathrm{CH}_{3}$ & $0.85, \mathrm{~d}(6.7)$ & $14.5, \mathrm{CH}_{3}$ & $0.83, \mathrm{~d}(6.7)$ & $14.1, \mathrm{CH}_{3}$ & $0.87, \mathrm{~d}(6.7)$ & $14.3, \mathrm{CH}_{3}$ & $0.86, \mathrm{~d}(6.7)$ \\
\hline 12 & $114.3, \mathrm{CH}_{2}$ & $5.29, \mathrm{~s} ; 5.08, \mathrm{~s}$ & $114.2, \mathrm{CH}_{2}$ & $5.33, \mathrm{~s} ; 5.09, \mathrm{~s}$ & $114.4, \mathrm{CH}_{2}$ & $5.27, \mathrm{~s} ; 5.09, \mathrm{~s}$ & $114.3, \mathrm{CH}_{2}$ & $5.30, \mathrm{~s} ; 5.09, \mathrm{~s}$ \\
\hline 13 & $128.7, \mathrm{CH}$ & $5.84, \mathrm{~m}$ & $128.7, \mathrm{CH}$ & $5.76, \mathrm{~m}$ & $128.8, \mathrm{CH}$ & $5.84, \mathrm{dd}(15.1,9.8)$ & $128.9, \mathrm{CH}$ & $5.77, \mathrm{dd}(15.1,9.8)$ \\
\hline 14 & $136.8, \mathrm{CH}$ & $5.23, \mathrm{~m}$ & $136.6, \mathrm{CH}$ & $5.35, \mathrm{~m}$ & $136.6, \mathrm{CH}$ & $5.18, \mathrm{~m}$ & 136.4, $\mathrm{CH}$ & $5.24, \mathrm{~m}$ \\
\hline 15 & $42.9, \mathrm{CH}_{2}$ & $2.11, \mathrm{~m} ; 1.68, \mathrm{~m}$ & 42.6, $\mathrm{CH}_{2}$ & $2.17, \mathrm{~m} ; 1.75, \mathrm{~m}$ & $43.3, \mathrm{CH}_{2}$ & $2.09, \mathrm{~m} ; 1.63, \mathrm{~m}$ & $43.2, \mathrm{CH}_{2}$ & $2.13, \mathrm{~m} ; 1.68, \mathrm{~m}$ \\
\hline 16 & $35.2, \mathrm{CH}$ & $1.23, \mathrm{~m}$ & $32.8, \mathrm{CH}$ & $1.52, \mathrm{~m}$ & $35.1, \mathrm{CH}$ & $1.16, \mathrm{~d}(6.4)$ & $33.5, \mathrm{CH}$ & $1.34, \mathrm{~m}$ \\
\hline 17 & $32.4, \mathrm{CH}_{2}$ & $1.63, \mathrm{~m} ; 0.65, \mathrm{~m}$ & $30.7, \mathrm{CH}_{2}$ & $1.68, \mathrm{~m} ; 0.89, \mathrm{~m}$ & $33.8, \mathrm{CH}_{2}$ & $1.54, \mathrm{~m} ; 0.62, \mathrm{~m}$ & $30.6, \mathrm{CH}_{2}$ & $1.62, \mathrm{~m} ; 0.79, \mathrm{~m}$ \\
\hline 20 & $43.8, \mathrm{CH}_{2}$ & $2.71, \mathrm{~m} ; 2.17, \mathrm{~m}$ & $42.7, \mathrm{CH}_{2}$ & $2.58, \mathrm{~m} ; 2.35, \mathrm{~m}$ & $74.5, \mathrm{CH}$ & $4.48, \mathrm{~s}$ & $76.0, \mathrm{CH}$ & 4.13, dd $(6.5,5.2)$ \\
\hline 21 & $148.9, \mathrm{CH}$ & $6.88, \mathrm{~m}$ & $149.0, \mathrm{CH}$ & $7.10, \mathrm{~m}$ & $151.4, \mathrm{CH}$ & 6.87, dd $(15.6,3.6)$ & $151.0, \mathrm{CH}$ & $7.03, \mathrm{dd}(15.7,5.1)$ \\
\hline 22 & $123.1, \mathrm{CH}$ & $5.64, \mathrm{dd}(15.6,0.8)$ & $123.5, \mathrm{CH}$ & $5.70, \mathrm{~d}(15.7)$ & $119.6, \mathrm{CH}$ & $5.81, \mathrm{~d}(15.6)$ & $121.1, \mathrm{CH}$ & $5.83, \mathrm{dd}(15.7,1.5)$ \\
\hline 23 & 166.0, C & & 166.1, C & & $166.2, \mathrm{C}$ & & $166.2, \mathrm{C}$ & \\
\hline 24 & $20.8, \mathrm{CH}_{3}$ & $0.90, d(6.6)$ & $20.5, \mathrm{CH}_{3}$ & $0.92, \mathrm{~d}(6.6)$ & $20.7, \mathrm{CH}_{3}$ & $0.89, \mathrm{~d}(6.6)$ & $20.5, \mathrm{CH}_{3}$ & $0.89, \mathrm{~d}(6.6)$ \\
\hline $1^{\prime}$ & $138.4, \mathrm{C}$ & & $138.8, \mathrm{C}$ & & $138.1, \mathrm{C}$ & & $138.3, \mathrm{C}$ & \\
\hline $2^{\prime}, 6^{\prime}$ & $131.0, \mathrm{CH}$ & $7.13, \mathrm{~d}(7.4)$ & $130.9, \mathrm{CH}$ & $7.16, \mathrm{~d}(7.4)$ & 131.1, $\mathrm{CH}$ & $7.13, \mathrm{~d}(7.4)$ & 131.0, $\mathrm{CH}$ & $7.14, \mathrm{~d}(7.4)$ \\
\hline $3^{\prime}, 5^{\prime}$ & $129.6, \mathrm{CH}$ & 7.26, dd $(7.4,7.4)$ & $129.6, \mathrm{CH}$ & 7.28, dd $(7.4,7.4)$ & $129.6, \mathrm{CH}$ & 7.26, dd $(7.4,7.4)$ & $129.6, \mathrm{CH}$ & 7.26, dd $(7.4,7.4)$ \\
\hline $4^{\prime}$ & $127.8, \mathrm{CH}$ & $7.18, \mathrm{t}(7.4)$ & $127.8, \mathrm{CH}$ & $7.20, \mathrm{t}(7.4)$ & $127.8, \mathrm{CH}$ & $7.18, \mathrm{t}(7.4)$ & $127.9, \mathrm{CH}$ & $7.18, \mathrm{t}(7.4)$ \\
\hline
\end{tabular}




\subsection{Antibacterial Assay}

The bacterium Pseudomonas syringae pv. actinidiae (Psa) was donated by Dr. He Yan of Northwest A \& F University. A sample of each culture was then diluted 1000-fold in fresh L-B broth and incubated with shaking $(160 \mathrm{rpm})$ at $27^{\circ} \mathrm{C}$ for $10 \mathrm{~h}$. The resultant mid-log phase cultures were diluted to a concentration of $5 \times 10^{5} \mathrm{CFU} / \mathrm{mL}$, and then $200 \mu \mathrm{L}$ was added to compound-containing plates. The minimum inhibition concentration (MIC) was determined by measuring bacterial growth after $24 \mathrm{~h}$ by performing 1:1 serial dilutions of each compound ranging from 1-128 $\mu \mathrm{g} / \mathrm{mL}$. Since there is no effective antibiotic drug against Psa, no positive control was included in this experiment.

\section{Conclusions}

Four cytochalasins divided as two pairs of epimers have been isolated from a kiwiassociated fungus of the genus Zopfiella. Their structures with absolute configuration were determined by means of spectroscopic methods and single-crystal X-ray diffraction. Compounds 1 and 3 showed anti-Psa activity. To the best of our knowledge, this is the first report of anti-Psa activity of cytochalasin derivatives. This research makes cytochalasins a potential application prospect in agricultural antibiotics.

Supplementary Materials: The following are available online. Spectra of 1D, 2D-NMR and HRESIMS for compounds 1-4 (PDF), X-ray crystallographic data of 1 and 3 (CIF).

Author Contributions: Conceptualization, T.F., J.H. and J.-K.L.; methodology, J.H. and Z.-H.L.; isolation, J.-Y.Z.; structural identification, J.-Y.Z., T.F. and J.H.; bioactivity screening, J.-Y.Z. and Z.-H.L.; writing and editing, T.F. and J.-K.L. All authors have read and agreed to the published version of the manuscript.

Funding: This work was financially supported by the National Natural Science Foundation of China (grant number: 22177139 and 22177138) and the National Key Research and Development Program of China (2017YFC1704007).

Institutional Review Board Statement: Not applicable.

Informed Consent Statement: Not applicable.

Data Availability Statement: Date of the compounds are available from the authors.

Acknowledgments: The authors would like to thank He Yan of Northwest A \& F University for the strain donation, and the Analytical and Measuring Center, School of Pharmaceutical Sciences, South-Central University for Nationalities, for spectroscopic data measurement.

Conflicts of Interest: The authors declare no conflict of interest.

Sample Availability: Not available.

\section{References}

1. Vanneste, J.L.; Cornish, D.A.; Yu, J.; Stokes, C.A. First Report of Pseudomonas syringae pv. actinidiae the Causal Agent of Bacterial Canker of Kiwifruit on Actinidia arguta Vines in New Zealand. Plant Dis. 2014, 98, 418. [CrossRef] [PubMed]

2. Testolin, R.; Ferguson, A.R. Kiwifruit (Actinidia spp.) production and marketing in Italy. N. Zeal. J. Crop Hortic. Sci. 2009, $37,1-32$. [CrossRef]

3. Ferrante, P.; Scortichini, M. Redefining the global populations of Pseudomonas syringae pv. actinidiae based on pathogenic, molecular and phenotypic characteristics. Plant Pathol. 2015, 64, 51-62. [CrossRef]

4. Opgenorth, D.C.; Lai, M.; Sorrell, M.; White, J.B. Pseudomonas canker of kiwifruit. Plant Dis. 1983, 67, 1283-1284. [CrossRef]

5. Serizawa, S.; Ichikawa, T.; Takikawa, Y.; Tsuyumu, S.; Goto, M. Occurence of bacterial canker of kiwifruit in Japan: Description of symptoms, isolation of the pathogen and screening of bactericides. Ann. Phytopathol. Soc. Jpn. 1989, 55, 427-436. [CrossRef]

6. Wang, R.L.; Li, Q.; He, S.S.; Liu, Y.; Wang, M.T.; Jiang, G. Modeling and mapping the current and future distribution of Pseudomonas syringae pv. actinidiae under climate change in China. PLoS ONE 2018, 13, e0192153. [CrossRef] [PubMed]

7. Cameron, A.; Sarojini, V. Pseudomonas syringae pv. actinidiae: Chemical control, resistance mechanisms and possible alternatives. Plant Pathol. 2014, 63, 1-11. [CrossRef]

8. Tyson, J.; Curtis, C.; Manning, M.; Rees-George, J.; Snelgar, W.; Blattmann, P. Systemic movement of Pseudomonas syringae pv. actinidiae in kiwifruit vines in New Zealand. N. Zeal. Plant Prot. 2014, 67, 41-47. [CrossRef] 
9. Stefani, E.; Giovanardi, D. Dissemination of Pseudomonas syringae pv. actinidiae through pollen and its epiphytic life on leaves and fruits. Phytopathol. Mediterr. 2012, 50, 489-496.

10. Mariz-Ponte, N.; Regalado, L.; Gimranov, E.; Tassi, N.; Moura, L.; Gomes, P.; Tavares, F.; Santos, C.; Teixeira, C. A synergic potential of antimicrobial peptides against Pseudomonas syringae pv. actinidiae. Molecules 2021, 26, 1461. [CrossRef] [PubMed]

11. Hao, N.; Han, L.R.; Li, Y.T.; Li, J.; Tian, X.L.; Kong, D.; Tian, X.R. New 8-O-4' neolignans and their antibacterial activity from the whole plants of Clematis lasiandra. ACS Omega 2020, 5, 19661-19666. [CrossRef] [PubMed]

12. Rao, J.R.; Liu, L.W.; Zeng, D.; Wang, M.W.; Xiang, M.; Yang, S. Antibiotic activities of propanolamine containing 1,4-benzoxazin-3ones against phytopathogenic bacteria. RSC Adv. 2020, 10, 682-688. [CrossRef]

13. Huang, X.; Liu, H.W.; Long, Z.Q.; Li, Z.X.; Zhu, J.J.; Wang, P.Y.; Qi, P.Y.; Liu, L.W.; Yang, S. Rational optimization of 1,2,3-triazoletailored carbazoles as prospective antibacterial alternatives with significant in vivo control efficiency and unique mode of action. J. Agric. Food Chem. 2021, 69, 4615-4627. [CrossRef] [PubMed]

14. Sun, L.T.; Chen, Y.; Yang, H.X.; Li, Z.H.; Liu, J.K.; Wang, G.K.; Feng, T. Bisabolane sesquiterpenes and $\alpha$-pyrone derivative from endophytic fungus Zopfiella sp. Phytochem. Lett. 2020, 37, 29-32. [CrossRef]

15. Yi, X.W.; He, J.; Sun, L.T.; Liu, J.K.; Wang, G.K.; Feng, T. 3-Decalinoyltetramic acids from kiwi-associated fungus Zopfiella sp. and their antibacterial activity against Pseudomonas syringae. RSC Adv. 2021, 11, 18827-18831. [CrossRef]

16. Evidente, A.; Andolfi, A.; Vurro, M.; Zonno, M.C.; Motta, A. Cytochalasins Z1, Z2 and Z3, three 24-oxa [14]cytochalasans produced by Pyrenophora semeniperda. Phytochemistry 2002, 60, 45-53. [CrossRef]

17. Evidente, A.; Andolfi, A.; Vurro, M.; Zonno, M.C.; Motta, A. Cytochalasins Z4, Z5, and Z6, three new 24-oxa[14]cytochalasans produced by Phoma exigua var. heteromorpha. J. Nat. Prod. 2003, 66, 1540-1544. [CrossRef] [PubMed]

18. Kim, E.L.; Wang, H.; Park, J.H.; Hong, J.; Choi, J.S.; Im, D.S.; Chung, H.Y.; Jung, J.H. Cytochalasin derivatives from a jellyfishderived fungus Phoma sp. Bioorg. Med. Chem. Lett. 2015, 25, 2096-2099. [CrossRef] [PubMed]

19. Wang, W.X.; Li, Z.H.; He, J.; Feng, T.; Li, J.; Liu, J.K. Cytotoxic cytochalasans from fungus Xylaria longipes. Fitoterapia 2019, 137, 104278. [CrossRef] [PubMed]

20. Steyn, P.S.; Breytenbach, J.C.; Botha, J.H.; Fernandes, M.A.; Wessels, P.L. Synthesis, complete 1H and 13C-NMR assignment and crystal structure of novel epoxide derivatives of cytochalasin B. Magn. Reson. Chem. 2008, 46, 650-659. [CrossRef] [PubMed] 